\title{
Vybrané podněty biskupských synod o rodině (2014, 2015) a postsynodální apoštolské exhortace Amoris laetitia (2016) pro pomáhající profese Jindřich Šrajer
}

Dvě zasedání biskupské synody o rodině z podzimu 2014, resp. 2015 a posynodální apoštolská exhortace o lásce v rodině papeže Františka Amoris laetitia z jara 2016 představují bezesporu jednu z nejvýznamnějších událostí či počinů v životě církve posledního období, především proto, že se věnují jednomu ze zásadních témat současnosti. Nejen předloženými výstupy, ale i způsobem, jak se k nim dochází, ${ }^{1}$ vzbuzují četné, byt’ kontroverzní reakce. ${ }^{2} \mathrm{Na}$ jedné straně jsou zde obavy ze zpochybnění tradičního učení církve v otázkách manželství a rodiny, resp. obavy o nepř́pustné přizpůsobení se duchu doby ze strany církve a rozmělnění jí dosud hlásaného ideálu manželského a rodinného života ve falešné snaze pomoci lidem, kteří v oblasti sexuálního, manželského či rodinného života selhali. Na straně druhé je to naopak radost z otevřenosti církve, s jakou se staví k problémům dnešní doby, z její odvahy pravdivě pojmenovat problémy manželského a rodinného života, hlavně se však s chápající láskou přiblížit $\mathrm{k}$ těm, kteří na této cestě klopýtli a klopýtají. ${ }^{3}$ Zmíněné synody a papežský dokument Amoris laetitia hledají odpovědi na palčivé a stále naléhavější problémy rodin, které jsou vystaveny řadě obtíží a nesnází, včetně snah o jejich samotnou destrukci. Synody i papežský dokument přitom nabízí řadu podnětů jak pro podobu církevní pastorační praxe, tak také pro oblast sociální práce. Pastorační práce není zaměřena pouze na řešení problémových jevů v oblasti manželských a rodinných vztahů, ale i na jejich prevenci. Sociální práce se cíleně soustředuje na problémové jevy v těchto životních oblastech. Rozdíl těchto dvou praxí tkví také $\mathrm{v}$ tom, že pastorační práce s manželstvími a rodinami vychází z principů křest̉anské víry, kdežto u sociální práce to není podmínkou ani obecným standardem. Sama tato skutečnost navozuje otázku, do jaké míry či zda vůbec mohou být podněty obsažené ve výstupních dokumentech obou synod a v posynodální apoštolské exhortaci, které vychází z křestanského pohledu na svět a u zainteresovaných ho předpokládají, pro sociální práci inspirativní. Předložené pojednání se této otázky implicitně dotýká specifikací konkrétních podnětů, resp. jejich praktického významu pro obě zmíněné praxe, čemuž předchází stručný pohled na podobu a význam křestanského etického paradigmatu v dějinách církve.

Srov. k tomu Heiner KOCH, Amoris laetitia. Eine Erläuterung, Stimmen der Zeit 6/2016, s. 364-366.

2 Spektrum rozdílných hodnocení dokumentu Amoris laetitia nekopíruje jednoduché schéma progresisté versus konzervativci. Toto spektrum je mnohem pestřejší. Srov. k tomu Walter KASPER, „Amoris laetitia“: Bruch oder Aufbruch?, Stimmen der Zeit 11/2016, s. 723-724.

3 Srov. např. Jindřich ŠRAJER, Nad synodou s nadějí, Universum 1/2015, s. 36-37. 


\section{Trvalý úkol církve - nově formulovat a zdůvodnit jí vlastní a smysl člověka utvářející hodnoty}

Chceme-li nabídnout reflexi o v současnosti možném přínosu křestanského étosu, formulovaném ve výše zmíněných církevních dokumentech, ke kultivaci manželství a rodiny, manželského a rodinného života, resp. pro kvalitní pastorační a sociální práci s rodinami, je dobré si v této souvislosti připomenout některé podstatné skutečnosti.

Církev, v koncilním pojetí dějinami putující Boží lid, je na jedné straně nositelkou neměnných Božích pravd. Na straně druhé je součástí světské společnosti, se kterou sdílí její radosti a naděje, bolesti a strasti. ${ }^{4}$ Církev tak nestvrzuje jen božský původ manželství a rodiny, resp. tradicí osvědčenou a církevní autoritou potvrzovanou představu o podobě zdařilého manželského a rodinného života, nýbrž je také opětovně konfrontována s trvalým úkolem nově formulovat a zdůvodnit jí vlastní a smysl člověka utvářející hodnoty. ${ }^{5} \mathrm{~K}$ tomu je nutné připomenout i její dějinně podmíněné postavení a role a s tím často spojenou podobu a význam jejího etického paradigmatu ve společnosti.

Je známou skutečností, že řada náboženských předpisů, jak je známe např. ze Starého zákona, jsou pouhými hygienickými předpisy či pravidly, které uspořádávají chod společnosti. Mají vést ke zdravému životu, k pokojnému a spravedlivému utváření vztahů ve společnosti, k jejímu dobrému fungování. V náboženských společnostech dochází nevyhnutelně k osmóze světského a náboženského, světského a církevního. Náboženské či církevní paradigma prostupuje celou společností a určuje její ráz. Zasahuje všechny její členy, pro které se stává nedílnou součástí jejich každodenního života. V západních evropských dějinách tuto významnou úlohu sehrávala po dlouhou dobu katolická církev. Měla v tomto směru dominantní postavení. Zaručovala homogenitu společnosti a bděla nad její morálkou. Nebylo tomu tak ale vždycky. Její paradigma v oblasti manželství a rodiny do značné míry kopírovalo společenské poměry a myšlenkové vzorce př́íslušného dějinného období a současně bylo často konkrétní reakcí na problematickou životní praxi.

Základem křestanské životní praxe je naplňování požadavku věrného následování Ježíše Krista, což mimo jiné znamená být nezřídka „znamením odporu“, kontrastovat se společensky a kulturně dominující životní praxí. Platilo to obzvláště pro počátky křestanství. Platí to ale bezesporu i pro současnost. ${ }^{6}$ Ve svých počátcích vnáší křestanství do antických rodinných společností a jim odpovídající životní praxe kritické podněty vưči rodině a individualisticko-emancipační impulsy. ${ }^{7}$ Ježíš potvrzuje původní stvořitelský záměr s manželstvím jako jedinečným a nerozlučitelným společenstvím muže a ženy (srov. Mt 19,3-9). Svým učením a postoji oceňuje hodnotu manželství (srov. Mt 9,15; 22,1-14; 25,1-13; J 2,1-12), důstojnost muže a ženy. Zároveň však relativizuje starozákonní výlučnost manželství. ${ }^{8}$ Upozaduje tradiční rodinné vztahy ve vlastní rodině (srov. Mt 12,46-50; Mt 8,21). Svým učením vnáší do rodinných vztahů rozkol (srov. Mt 10,34-36). První křestané se přitom ptají po opodstatněnosti manželství a způsobu jeho prožívání vzhledem k přijetí křestanské víry, na což se jim dostává střídmé, zato však konkrétní odpovědi formou

Srov. Gaudium et spes 1 .

5 Srov. Franz X. KAUFMANN, Ehe und Familie zwischen kultureller Normierung und gesellschaftlicher Bedingtheit, in: Anton RAUSCHER, Handbuch der Katholischen Soziallehre, Berlín: Duncker Humblot, 2008, s. 257.

6 Srov. Amoris laetitia 200.

7 Srov. André HABISCH, Zukunftfähigkeit und Gesellschaftspolitik. Familienorientierte Institutionengestaltung als Herausforderung des 21. Jahrhunderts, in: Wolfgang OCKENFELS (ed.), Familien zwischen Risiken und Chancen, Paderborn: Ferdinand Schöningh, 2001 , s. 32.

8 Manželství je ve Starém zákoně základní povinností, která nemá životní alternativu. Srov. k tomu Johannes B. BAUER, Ehe, in: Bibeltheologisches Wörterbuch, Graz - Wien - Köln: Styria, 1994, s. 112. V Novém zákoně představuje vedle manželství další životní alternativu panenství (Mt 19,11n). 
několika málo doporučení a pastoračních rad (srov. $1 \mathrm{~K} 7$ ).

Církevní paradigma ohledně manželství a rodiny, jež byla po značně dlouhou dobu charakterizována stabilitou „domu“ (velkorodin) - „integritou ,domu', společenství a místa“, s nezpochybňovanou, ekonomickými zájmy podmíněnou stabilitou, vyznačující se soudržností generací, manželů a rodičů s dětmi, ${ }^{10}$ se po novozákonní době „zakonzervováváa $\mathrm{v}$ úvahách a učení o účelu manželství. Manželství a rodina jsou, především pod vlivem Augustinova učení o manželství a manželských dobrech, ${ }^{11}$ jednostranně, ne-li výhradně, oceňované pro službu životu. Hodnota partnerského vztahu se nedoceňuje či př́lišs nereflektuje. ${ }^{12}$ Tuto po dlouhou dobu zastávanou dogmatickou setrvačnost v učení církve o manželství „nezviklaly“ ani nastupující změny společenských poměrů, ke kterým dochází zvláště v období po Francouzské revoluci a nástupem průmyslové revoluce. Přehlížení těchto změn, ke kterým patřilo zvláště posilování významu intimního života v manželství, manželského vztahu a změny funkcí rodiny, ze strany církve znamená oslabení jejího společenského významu a autority. Její poselství nabývá stále více antikvujícího charakteru.

Změnu ve výše zmíněném ohledu přináší teprve II. vatikánský koncil (1962-1965), resp. pastorální konstituce Gaudium et spes (GS). Při vědomí neměnného (božského) původu manželství a rodiny je zde reflektován jejich aktualizovaný význam v kontextu nastalých společenských, hospodářských a životních poměrů. Manželství je zde prezentováno jako společenství lásky a života, s vyváženým důrazem na hodnotu manželské lásky a službu životu. ${ }^{13}$ Byt’ se zásadní změna oproti dřívějšímu paradigmatu týkajícímu se manželství a rodiny nerodila na koncilu snadno, což se mimo jiné odráží v některých rozporuplnostech výsledného kompromisního textu, přesto zde bylo založeno paradigma nové, biblicky ukotvené, charakterizované svou otevřeností k aktuálním poznatkům exaktních věd s cílem poctivě zachytit současnou realitu v oblasti manželství a rodiny a předložit srozumitelnou pobídku pro plnohodnotné prožívání manželských a rodinných vztahů. ${ }^{14}$

V době po koncilu je ve vyjádřeních papežů Pavla VI. (1963-1978), Jana Pavla II. (1978-2005) a Benedikta XVI. (2005-2013) opakovaně akcentován antropologický a teologický základ manželství a rodiny. Zdůrazňuje se přirozenost těchto institucí, tedy to, že pravda o nich „je zakotvena v pravdě o člověku“. ${ }^{15} \mathrm{Z}$ tohoto základu se následně dedukují v něm obsažené závazné normy, které mají utvářet manželské a rodinné vztahy a z nich vyplývající úkoly (např. v oblasti předávání života). Benedikt XVI. se přitom snaží dokázat, že postoje křestanské etiky nejsou vzdáleny obecné lidské zkušenosti, realitě tohoto světa a s ní spojeným otázkám. Jejím cílem není, dle jeho slov,

9 Miloslav PRŮKA, Péće o oikos. Dưm v dějinách myšlení, edice Pontes Pragenses, sv. 55, Brno: L. Marek, 2009, s. 81. Lubomír Mlčoch v návaznosti na řečené poukazuje na mnohovrstevný význam „domu“ (velkorodiny), který „zahrnoval jednotu obydlí, majetku, široce založenou rodinu včetně ,dědictví otcư, společenství víry i způsob života a vedení hospodářstvi', což podle něho, jak správně uvádí, v českých podmínkách přetrvalo v mnohém „až do specificky pojaté modernizace ,reálného socialismu““. Lubomír MLČOCH, Ekonomie rodiny v proměnách času, institucí a hodnot, Studie Národohospodářského ústavu Josefa Hlávky, Praha, 2013, s. 7. K charakteristice velkorodiny srov. také Anton RAUSCHER, Znovuobjevení rodiny, ediční řada Ordo socialis, Brno: CDK, 1996, s. 3, 5-6.

10 Srov. Anton RAUSCHER, Znovuobjevení rodiny, s. 4.

11 K Augustinovu pojetí manželství srov. Michael MÜLLER, Paradiesehe. Die Lehre des Hl. Augustinus von der Paradiesehe und ihre Auswirkung in der Sexualethik des 12. und 13. Jahrhunderts bis Thomas von Aquin, Regensburg: Friedrich Pustet, 1954.

$12 \mathrm{~V}$ tradiční katolické morální teologii a kanonickém právu je manželství pojímáno jako hierarchické společenství manželských dober a cílů. Nejvyšším z nich, ostatním nadřazeným, je plození a výchova potomstva. Srov. CIC 1917 kán. 1013, $\$ 1$.

13 Srov. Gaudium et spes 47-52. Srov. k tomu také Jindřich ŠRAJER, Nové pojetí manželství, Teologické texty 1/2003, s. 17-19.

14 Srov. k tomu Jindřich ŠRAJER, O důstojnosti manželství a rodiny, in: Jindřich ŠRAJER - Lucie KOLÁŘOVÁ a kol., Gaudium et spes padesát let poté, Brno: CDK, 2015, s. 168-205.

15 Srov. BENEDIKT XVI., Myšlenky o rodině, výbor z textů papeže Benedikta XVI. uspořádal Lucio Coco, Praha: Paulínky, 2010, s. 24. Papež Benedikt XVI. dokladuje tuto skutečnost mimo jiné poukazem na kulturní dějiny lidstva, které jsou poznamenané hříchem, zatemněním původního významu manželství, přesto si však je, podle něho, člověk stále vědom toho, že všechny jiné formy vztahu mezi mužem a ženou (než manželství) odporují původnímu plánu s člověkem. Zvláště velké kultury podle Benedikta XVI. opětovně směřují k monogamii, ke společenství muže a ženy, kteří tvoří jedno tělo. Srov. tamtéž, s. 29. 
potlačovat lidské hodnoty či projevy, ${ }^{16}$ nýbrž vnášet do obecně lidské zkušenosti specifický pohled, který tuto zkušenost očištuje, proměňuje, rozlišuje a ozdravuje, resp. vyzdvihuje a ve světle Boží lásky přivádí $\mathrm{k}$ naplnění všechno, co je opravdově lidské. ${ }^{17}$ Zároveň však otevřeně připouští i jistou neschopnost zastávané hodnoty dobře sdělovat druhým, zvláště mladým lidem, kteří mají podle jeho slov strach před definitivním rozhodnutím se pro manželství, a zároveň je u nich třeba odbourávat hluboce zakořeněný předsudek, „že křestanství klade se svými přikázáními a zákazy př́liš překážek radosti z lásky, a zvláště, že nedovoluje zakoušet plně ono štěstí, které muž a žena nacházejí ve své vzájemné lásce “. ${ }^{18}$ Obecně se dá rríct, že zmínění tři pokoncilní papežové usilují primárně o prezentaci ideálu manželství a rodiny spolu se snahou předkládat tento ideál k pochopení ze strany člověka. Jinak řečeno, primární snaha o vycizelování ideálu manželství a př́lišný důraz na platnost objektivního mravního zákona, který je nutné dodržovat, je zároveň do jisté míry přehližením či nepř́lišným zohledněním často problémové a komplikované reality, ve které se jednotlivci nezřídka ocitají. $V$ dosavadním církevním paradigmatu to, zdá se, představuje nedocenění jejich zodpovědné svobody či snad dokonce primární nedůvěru v ní.

Papež František navazuje na koncilní a pokoncilní naukovou linii ohledně manželství a rodiny. Vnáší do ní ovšem nové akcenty a podněty, nastoluje nové etické paradigma. Toto paradigma se nevyhýbá pokorně sebekritickému hodnocení dosavadního způsobu předkládání křestanských zásad a př́stupu $\mathrm{k}$ lidem $\mathrm{v}$ oblasti manželství a rodiny. Papež přitom mluví zcela konkrétně. Otevřeně pojmenovává problematické prrístupy a formuluje nové požadavky vzhledem $\mathrm{k}$ prezentaci manželství a jeho pastoraci. Kritizuje dosavadní př́lišnou idealizaci manželství, které se tím podle něho stává $\mathrm{v}$ očích lidí abstraktním, neatraktivním a téměř uměle vykonstruovaným. ${ }^{19} \mathrm{Za}$ neúčelné považuje rétorické pranýřování dnešních nešvarů, $\mathrm{v}$ dějinách církve mnohokrát zaujímaný obranný postoj, mrhání energií četnými výpady proti upadajícímu světu a nedostatečné ukazování cesty ke štěstín ${ }^{20}$ a také to, že poselství církve o manželství a rodině neodráželo „jasně kázání a postoje Ježiše, který předkládal náročný ideál, ale současně nikdy neměl daleko $\mathrm{k}$ soucitu se slabými lidmi, jako se Samařankou nebo s cizoložnou ženou“.21 Papež František přitom připomíná, že jenom důrazem na věroučné, bioetické a morální otázky bez podpory $\mathrm{k}$ otevření se milosti nelze dostatečně povzbudit rodiny $\mathrm{v}$ upevňování manželského svazku a naplňování svého společného života smyslem. Pléduje naopak pro postup „představovat manželství spíše jako dynamickou cestu růstu a realizace než jako břemeno, které je nutné nést celý život“.22 Vyslovuje se pro respektování „svědomí věřících, kteří v mnoha případech odpovídají co možná nejlepším způsobem na evangelium $\mathrm{v}$ rámci svých omezení a mohou růst ve svém osobním rozlišování v situacích, ve kterých selhávají všechna schémata. Jsme povoláni,“ jak zdůrazňuje, „svědomí vychovávat, a ne je nahrazovat. “23 Tento papežův přístup je pro něho zároveň základním výchozím bodem pro rozvíjení představ o konkrétní podobě pastorační praxe, které lze v mnoha ohledech aplikovat i na sociální práci.

16 Viz Nietscheho kritika křestanství, které mělo dát érotu (tělesné lásce) vypít jed, degradovat ho na pouhou neřest. Srov. k tomu Deus caritas est 8.

17 Srov. Joseph RATZINGER, Obnova morální teologie. Perspektivy 2. vatikánského koncilu a encykliky Veritatis splendor, Communio 3/2006, s. 307.

18 BENEDIKT XVI., Myšlenky o rodině, s. 116.

19 Srov. Amoris laetitia 36.

20 Srov. tamtéž, 35, 38.

21 Tamtéž, 38.

22 Tamtéž, 37.

23 Tamtéž. 


\section{Pastorační péče blízká člověku}

Konkrétní podněty pro podobu pastorační praxe nabízí papež František v šesté kapitole Amoris laetitia. Hned v jejím úvodu připomíná, že nechce předkládat nějakou nauku o pastoraci rodin, ale jen obecně nastínit nové pastorační metody, jejichž praktičtější a účinné návrhy by měly v souladu s naukou církve vypracovat jednotlivá společenství, která mohou zohlednit místní potřeby a požadavky. ${ }^{24}$ Toto vyjádření předznamenává důležité akcenty, které charakterizují papežovu představu o podobě pastorační praxe, totiž relativizaci římského centralismu a podporu subsidiárního modelu pastorální odpovědnosti. Znamená to mimo jiné, „že ne všechny věroučné, morální nebo pastorační diskuse musejí být vyřešeny zásahem magisteria“, ${ }^{25}$ resp. to, že na všechny otázky neexistuje jedna odpověd. Papež zdůrazňuje, že v církvi je „nezbytná jednota nauky a praxe“ ${ }^{26}$ to však nebrání tomu, „aby existovaly různé způsoby interpretace některých hledisek nauky nebo některých důsledků z ní plynoucích (...) každý obecný princip, má-li být zachován a aplikován, potřebuje být inkulturován. “27

Tyto papežovy akcenty vychází z jeho často opakované myšlenky o nadřazenosti času nad prostorem. V této souvislosti hovoří o napětí mezi plností a omezením, které je třeba umět unést. Prostor či spíše postoj mít všechno hned znamená podle papeže omezení. Čas „pojímaný v širokém smyslu se (naopak) vztahuje k plnosti a vyjadřuje horizont, který se před námi otvírá. “28 Papež považuje princip, kdy je čas nadřazen prostoru, za princip pokroku. Umožňuje totiž „pracovat dlouhodobě, bez posedlosti okamžitými výsledky“. ${ }^{29}$ Ve vztahu k manželství a rodině to znamená vnímat dynamiku a komplexnost procesu utváření těchto institucí směrem $\mathrm{k}$ ideálu, který se před nimi otevírá jako dosažitelná perspektiva. Manželství a rodina jsou lidskou skutečností, která není ideálem, nýbrž komplexem, který v mnoha ohledech potřebuje spásu. Rodiny nejsou z tohoto papežova pohledu „problém, nýbrž především př́íležitost“ ${ }^{30}$ Papežem prezentovaný široký pohled na komplexitu životních skutečností manželství a rodiny podněcuje pastoraci, která není redukována na mechanickou aplikaci norem. Může být realizována jen prostřednictvím příslušných zodpovědných osob (pastoračních pracovníků, kněží, místního biskupa) jako kreativní proces zprostředkování mezi konkrétním člověkem, jeho životní situací a učením církve. ${ }^{31}$ To také předpokládá, že „uvažování pastýřů a teologů, pokud je vedeno věrností církvi a je poctivé, realistické a kreativní, pomáhá dojít větší jasnosti ve věroučných, morálních, duchovních a pastoračních otázkách. “"32

Ústředním motivem pastorační práce má přitom být radost, resp. radostná láska, která je navázána na milosrdenství. To je zlatá nit pastorální teologie současného papeže, která se vine jeho pastorálními texty. Křestanská zvěst o rodině má být vpravdě radostným poselstvím, které je odpovědí na touhu po rodině, jež je živá zvláště mezi mladými lidmi. ${ }^{33}$ Papež chce podnítit křestanské rodiny, aby si vážily daru manželství a rodiny, aby „plně milovaly hodnoty, jako jsou velkodušnost,

\footnotetext{
Srov. Amoris laetitia 199.

Tamtéž, 3.

Tamtéž.

Tamtéž.

Evangelii gaudium 222.

Evangelii gaudium 223

Amoris laetitia 7.

31 Srov. Marianne HEIMBACH-STEINS - Denise MOTZIGKEIT - Janine REDEMANN - Karolin FRERICH - Petr ŠTICA, Familiale Diversität und pastorale Unterscheidung. Eine theologisch-ethische Analyse zum nachsynodalen Schreiben Amoris laetitia, Sozialethische Arbeitspapiere des Instituts für Christliche Sozialwissenschaften 5/2016, Münster: Institut für Christliche Sozialwissenschaften, s. 12.

32 Srov. Amoris laetitia 2.

33 Srov. tamtéž, 1.
} 
iniciativnost, věrnost a trpělivost. ${ }^{“ 34}$ Chce zároveň povzbudit „,šechny, aby byli znamením milosrdenství a blízkosti tam, kde se rodinný život neuskutečňuje dokonale nebo neprobíhá v pokoji a radosti. ${ }^{\text {" }} 3$

Text Amoris laetitia je tak prost jakéhokoliv dogmatismu či antagonismů. Neomezuje se na zákazy a doktrinální vymezení. Papež výslovně varuje před „chladnou byrokratickou morálkou“, ${ }^{36}$ před „aplikováním morálních zákonů, jako by to byly kameny, které je možné házet na život lidí. “ ${ }^{37}$ Předkládá text, jenž se vyznačuje jednoduchostí, pozitivním a povzbuzujícím akcentem. Papežovým hlavním záměrem je připomenutí toho nejpodstatnějšího pro pastoraci: hlásání radostné zvěsti Ježíše Krista pro životní oblasti manželství a rodiny. Prakticky to znamená, že pastýři mají s citlivostí a klidem naslouchat a s upř́mnou touhou vstupovat do dramatu lidí a pochopit jejich pohled na věc, a tak jim pomáhat lépe žít a poznávat jejich místo v církvi. ${ }^{38}$

Pastorální perspektivu, resp. její akcenty, jak jsou předkládány papežem Františkem v Amoris laetitia, lze nakonec vtěsnat do tř́i slov: doprovázení, rozlišování, začleňování.

Papež zdůrazňuje naléhavost doprovázení před uzavřením manželství, ale i v průběhu manželství, zvláště pak $\mathrm{v}$ jeho počátečních fázích. Za nedostatečnou považuje redukci př́ípravy na manželství do formy krátkodobé katecheze víry a manželského života, která bezprostředně předchází uzavření sňatku. Pomineme-li jím připomínanou skutečnost, že každý člověk se de facto připravuje na manželství již od svého narození, ${ }^{39}$ zdůrazňuje potřebu dlouhodobé př́pravy na manželství uskutečňovanou místním společenstvím, které má nabízet zvláštní programy bezprostřední přípravy na manželství. V intencích jím položeného akcentu na důležitost citového života v manželství, resp. manželské lásky, jak jí exkluzivně prezentuje ve 4. kapitole Amoris laetitia, připomíná, že svatba nemá být brána jako konec cesty. Manželství je totiž povolání, které se má objevovat a rozvíjet po celý život. Znamená to, že předmanželská pastorace, ale i pastorace manželů, se má zaměřovat na manželský svazek, a má přitom párům pomáhat nejen prohlubovat jejich lásku, ale také učit se překonávat problémy a obtíže.$^{40}$ Páry by měly rovněž obdržet potřebné informace „o místech a osobách, poradenských službách nebo ochotných rodinách, na které se mohou obrátit s prosbou o pomoc".41

Jak bylo řečeno, papež klade důraz na doprovázení, zvláště pak na doprovázení manželů v prvních letech společného života. V intencích výstupních dokumentů, které shrnují výsledky diskuse dvou biskupských synod o rodině, zdůrazňuje papež František potřebu pastoračního doprovázení, která je již dříve zmiňovaná v dokumentech magisteria. Zatímco dosud bylo tímto myšleno „spíše usnadnění cesty manželů $\mathrm{k}$ tomu, aby dobře zvládali jim svěřené úkoly, především odpovědnou službu životu, a žili křestanským způsobem života", ${ }^{2}$ papež František nadto vyzdvihuje také důležitost jejich doprovázení k citové zralosti, resp. zralosti jejich vzájemného vztahu. ${ }^{43}$ Zvláštní význam přitom mohou sehrát zkušenější manželské páry, které jim formou párového doprovázení, jak je napřr. rozpracovává publikace Doprovázení mladých manželů ke zralému vztahu, ${ }^{44} \mathrm{k}$ tomu

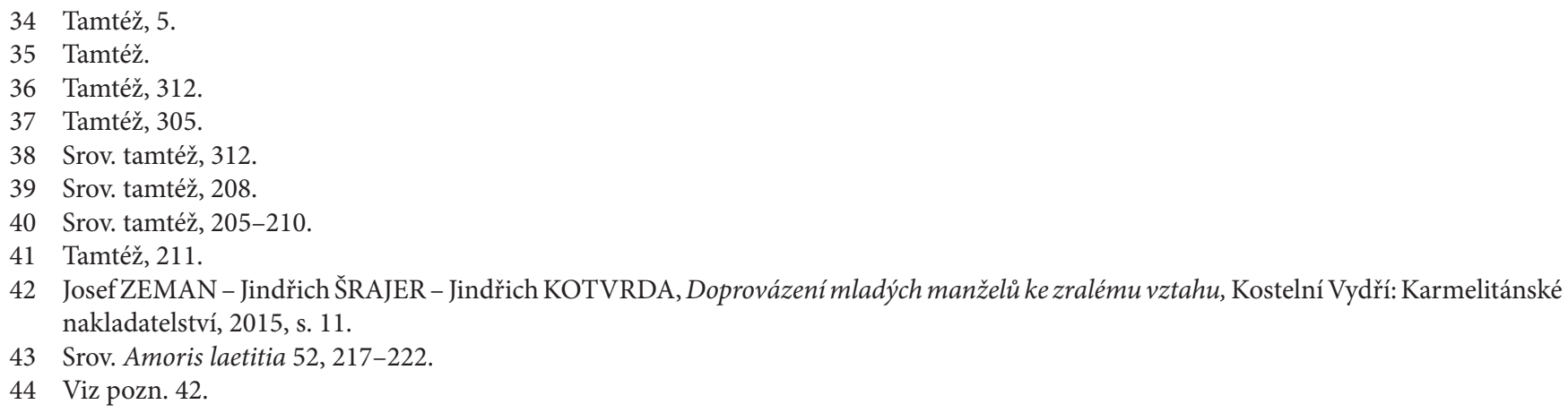


mohou významně dopomoci. Závěry obsažené v této publikaci souzní s pozicemi papeže Františka, který poukazuje na to, že v manželském svazku se „manželé stávají protagonisty, pány svých dějin a tvưrci plánu, který mají společně naplňovat. "45 Patří k tomu trvalé cvičení se ve vzájemné lásce. To představuje mimo jiné každodenní vzájemné vyjednávání, které „tvoří předivo vzájemných nabídek a odř́kání se pro dobro rodiny. “ ${ }^{46}$ Nejde přitom o to, aby byli „vítězové a poražení, nýbrž aby vyhráli oba dva... každá domácnost je jedinečná a každé manželství najde jiný způsob, jak věci uspořádat. " ${ }^{47} \mathrm{~V}$ neposlední řadě papež František v návaznosti na představení některých zdrojů pomoci v pastoraci rodin připomíná, že tato „musí být dnes podstatně misijní, ... je třeba jít ven, kde jsou lidé. Už nemůžeme být pouze továrnou na kurzy, které navštěvuje jen pár lidí. “48 Dále papež František formuluje vzhledem ke krizím či krizovými situacím v manželství a rodině požadavek rozlišování a integrace. Předně připomíná, že „každá krize v sobě skrývá radostnou zvěst “, ${ }^{49}$ kterou je třeba umět zaslechnout. ${ }^{50}$ Papež přitom vyjmenovává různé druhy krizí, které přirozeně vyvstávají v rámci manželství a rodinného života, jako jsou např. krize při dospívání dítěte či krize způsobená stárím rodičů manželů. ${ }^{51}$ Papež přitom vyzdvihuje význam pastorační pomoci, kterou ovšem většina potřebných nevyhledává, protože ji „nepovažuje za rozumnou, blízkou, realistickou a ,vtělenou“ “ 52 Vzhledem k dalším situacím, které je nutné pečlivě rozlišovat, jako je tomu u pastoračního doprovázení odloučených, rozvedených a opuštěných manželů, by měla být pastorační péče charakteristická svojí osobní blízkostí. Měla by vnímat a mít na zřeteli bolest zainteresovaných, zvláště dětí. Tato péče by měla zahrnovat smíření a mediaci, měly by být $\mathrm{k}$ dispozici odborná poradenská centra. Lidé ocitající se v problémových situacích by měli být podle papeže integrováni do křestanského společenství a farních pastoračních institucí. ${ }^{53} \mathrm{~V}$ neposlední řadě si papež všímá i situace rodiny, v níž některý ze členů projevuje homosexuální sklony, nebo situace nastalé úmrtím některého $\mathrm{z}$ členů rodiny a jeho dopadem na pozůstalé. $\mathrm{V}$ obou těchto prrípadech se vyslovuje pro citlivý přístup a náležitou pozornost a ochotu, která se vưči potřebným v takových př́ípadech vyžaduje. ${ }^{54}$

\section{Rozlišsování v konfliktních situacích a integrace}

Zatímco doprovázení je spojeno více s objevováním a podporou pozitivních očekávání a perspektiv u doprovázeného, požadavek rozlišování a začleňování či integrace se vztahuje primárně na konfliktní a problémové situace a jejich řešení. V tomto směru se to týká nejen pastorační praxe, ale eminentně právě i praxe sociální práce. Jde přitom především o náležité etické rozlišování v kolizních situacích.

Jak je patrné z již výše řečeného, papež František nenabízí v Amoris laetitia jednoznačná řešení pro sporné dogmatické, morálně teologické, církevně právní nebo pastorálně teologické problémy. Jeho důraz je položen na subsidiární naplňování odpovědnosti na všech př́ílušných úrovních pastorační pomoci s doceněním osobního svědomí jednotlivce jako instance schopné rozlišování. Tato papežova pozice je biblicky doložená, zakořeněná v jemu vlastní ignaciánské spiritualitě

\footnotetext{
Amoris laetitia 218.

6 Tamtéž, 220.

Tamtéž.

Tamtéž, 230.

Tamtéž, 232.

Srov. tamtéž, 232.

Srov. tamtéž, 235.

Tamtéž, 234.

Srov. tamtéž, 241-246.

Srov. tamtéž, 250, 253-258.
} 
a teologicky zpětně navázaná na scholastickou tradici. Znamená to pečlivé rozlišování jednotlivých situací a z nich vyplývajících požadavků a tomu odpovídající pastorálně-etické rozhodování na místně př́slušných úrovních ${ }^{55}$ Pro pastorační praxi, ale přeneseně i pro sociální práci, to znamená vyzdvižení osobní odpovědnosti pastoračních a sociálních pracovníků, která se nemůže skrýt za striktní aplikaci etické normy či zákona, ani neumožňuje schovávání se za instituci církve, ${ }^{56}$ či za nastavená kritéria či standardy pomáhající organizace v oblasti sociální práce. V konceptu pastoračních perspektiv předkládaném papežem Františkem je kladen důraz na osobní angažovanou interakci mezi pastoračním pracovníkem, manžely a rodinou, pro oblast sociální práce lze vztáhnout na interakci mezi sociálním pracovníkem a klientem, resp. klienty (manželi, rodiči apod.). Nestačí přitom „uvažovat jen o tom, zda jednání osoby odpovídá nebo neodpovídá nějakému zákonu nebo obecné normě ${ }^{57}$ Podle papeže by to bylo nejen zjednodušující, ale i nedostatečné vzhledem k perspektivám člověka. Šlo by o postoj „zavřených srdcí ${ }^{\prime \prime}{ }^{58}$ povýšeneckého a povrchního posuzování obtížných př́ípadů a zraněných rodin. ${ }^{59}$

Angažovaný přístup pomáhajících pracovníků má být podle papeže prodchnut něhou. Tito pracovníci si mají osvojovat „logiku soucítění vưči těm, kdo jsou slabí a vyhýbat se jejich stíhání nebo prriliš tvrdým a unáhleným soudům. “60 $\mathrm{V}$ opačném případě to znamená, že pastorační či sociální pracovníci neberou v potaz složitost různých situací a nevnímají život a utrpení lidí prožívajících tyto těžkosti. Za nepř́ípustné se rovněž považuje definitivní odsouzení člověka ${ }^{61}$ Tyto důrazy bezesporu nalézají své zdůvodnění v biblické a křestanské tradici, přesto zde nelze nepřipomenout rizika pomáhajících pracovníků, jako je např. „mesiášský komplex“ či syndrom vyhoření. Papež tato rizika, resp. možné osobní limity pomáhajících pracovníků explicitně nezohledňuje, byt z celkového kontextu jeho textu vyplývá, že vnímá ohraničení lidské odpovědnosti, jak je konstituováno vztahem člověka $\mathrm{k}$ Bohu. Primární odpovědnost za vše náleží Bohu Stvořiteli, u něhož člověk nalézá pomoc a útěchu. To platí i v př́padě, kdy papež vyzývá $\mathrm{k}$ tomu, aby se přestaly hledat osobní či společenské úkryty, které člověku umožní zachovat si odstup od lidského dramatu. Pokud se člověk podle něho odhodlá vstoupit do kontaktu s konkrétní existencí druhých, zakusí moc něhy. ${ }^{62} \mathrm{Na}$ druhou stranu se tím člověku život „vždy úžasně zkomplikuje“. ${ }^{63}$

$\mathrm{V}$ papežových pastoračních výzvách $\mathrm{k}$ doprovázení, rozlišování a začleňování $\mathrm{v}$ pastorační praxi a v přeneseném slova smyslu také $\mathrm{v}$ sociální práci je zahrnut jím opakovaně zdůrazňovaný požadavek respektování procesu zrání u každého člověka, který vyžaduje od pomáhajících pracovníků časovou disponibilitu, vytrvalost a trpělivost. Obzvláště v praxi sociální práce však mohou sociální pracovníci narážet na „vnější překážky“, které jim naplňování zmíněného požadavku znemožňují, mnohdy i při jejich dobré vưli. Jde především o $\mathrm{z}$ tohoto pohledu často nadměrnou administrativní zátěž kladenou na sociální pracovníky - nutnost vyplňovat formuláře, dělat zápisy ze setkání apod. Na místě je přitom také otázka, nakolik je to problém systému, a nakolik to může být v některých případech pro sociálního pracovníka spiše i jistý druh výmluvy, když nemá odvahu či chut problémové klienty dlouhodobě doprovázet. $V$ některých institucích se hlubší

55 Srov. Marianne HEIMBACH-STEINS - Denise MOTZIGKEIT - Janine REDEMANN - Karolin FRERICH - Petr ŠTICA, Familiale Diversität und pastorale Unterscheidung, s. 1.

56 Srov. Amoris laetitia 305.

57 Tamtéž, 304.

58 Tamtéž, 305.

59 Srov. tamtéž, 305.

60 Tamtéž, 308.

61 Srov. tamtéž, 296.

62 Srov. tamtéž, 308.

63 Tamtéž, 308. 
rozhovor s klientem a jeho dlouhodobé doprovázení dokonce přímo zakazují.

Za papežovými pastoračními výzvami, jak již bylo výše naznačeno, se skrývá promyšlená teologická pozice, která čerpá z bohatství křest’anské tradice a dosavadního učení církve. Toto bohatství nebylo dosud, zdá se, dostatečně zohledněno, resp. nebylo mainstreamovou záležitostí. Papež se přitom odvolává především na Tomáše Akvinského a svého předchůdce v úřadu Jana Pavla II. Papežovy postoje ale nalézají oporu i u soudobých autorů, jako je např. německý etik Konrad Hilpert, který exkluzivním způsobem reflektuje jednotlivé aspekty v etice zdůrazňované osobní odpovědnosti. ${ }^{64}$

Nutnost respektování procesu zrání u každého člověka, která předpokládá znalost jeho konkrétních podmínek, míry poznání či pochopení objektivních požadavků zákona, opírá papež František o takzvaný „zákon postupnosti“, formulovaný Janem Pavlem II. Spolu s ním upozorňuje, že to neznamená „odstupňování zákona“. Zákon neztrácí nic ze své platnosti. ${ }^{65}$ Zohledňuje se tím jen odlišný stupeň odpovědnosti v jednotlivých př́padech. „Důsledky nebo účinky jedné normy nemusejí být (totiž) nutně vždy stejné. “66 Jinak řečeno, nejde o to snižovat nároky evangelia, nýbrž reflektovat polehčující okolnosti. Prakticky to znamená, že všichni, kteří se nacházejí vzhledem k objektivnímu požadavku zákona v tzv. iregulární situaci, nejsou automaticky smrtelnými hř́šsníky ${ }^{67}$ Zásadně je zdůrazněno, že byt konkrétní osoba zná dobře normu, neznamená to ještě, že přitom nemůže mít velké obtíže s pochopením hodnot, o které u dané mravní normy jde, „nebo se může nacházet v konkrétních podmínkách, které (jí) nedovolí jednat odlišně a učinit jiná rozhodnutí, aniž by se obtížila novou vinou. “68 Mohou totiž „existovat okolnosti, které omezují schopnost rozhodování. “69 S odkazem na Katechismus katolické církve papež František připomíná, že „přičitatelnost a odpovědnost za nějaké jednání může být snížena a dokonce potlačena neznalostí, roztržitostí, násilím, strachem, návyky, bezuzdnými vášněmi a jinými psychickými nebo sociálními činiteli“. Řadí sem i „citovou nezralost, sílu získaných návyků, stavů úzkosti nebo jiných psychických či sociálních činitelü“ “70

Papež František tak zřetelně přesouvá dosavadní akcent hodnocení morálního činu od jeho skutkové podstaty směrem $\mathrm{k}$ subjektu jednání, $\mathrm{k}$ reflexi jeho dispozic. Akcentuje se tím odpovědnost pastoračních pracovníků, kteří mají poctivým rozlišováním v jednotlivých situacích napomáhat ke zrání svědomí člověka. Zahrnuje to mimo jiné poznání, že určitá konkrétní situace sice neodpovídá obecnému požadavku evangelia, ale za daných okolností představuje velkodušnou odpověd’ Bohu v rámci aktuálních lidských omezení, aniž by se tím zpochybňovala otevřenost novým fázím růstu a novým rozhodnutím, které umožní dotyčnému dosáhnout kýženého ideálu. ${ }^{71}$

Zmíněnou změnu paradigmatu směrem od hodnocení činu dle jeho skutkové podstaty k vážení dispozic jednajícího subjektu opírá papež František o morálku ctností Tomáše Akvinského. Tomáš Akvinský v návaznosti na aristotelovskou tradici klade ctnost do středu mezi dva extrémy, také mezi extrémy rigorismu a laxismu. Rozlišuje přitom mezi spekulativním a praktickým rozumem. Zatímco spekulativní rozum odvozuje následky striktně logicky z principů, v praktické oblasti toto není možné. V ní nastavené objektivní normy nejsou dokonalé, představují jistou míru zobecnění. Nejsou s to zachytit všechny okolnosti života. Aplikace těchto norem se tak ne-

64 Srov. Konrad HILPERT, Zentrale Fragen christlicher Ethik: Für Schule und Erwachsenenbildung, Regensburg: Friedrich Pustet, 2009.

65 Srov. Amoris laetitia 295.

66 Tamtéž, 300

67 Srov. tamtéž, 301.

68 Tamtéž, 301.

69 Tamtéž.

70 Tamtéž, 302, resp. Katechismus katolické církve 1735, 2352.

71 Srov. Amoris laetitia 303. 
může provádět pomocí logické dedukce, nýbrž prostřednictvím ctnosti moudrosti či prozřetelnosti. Ta se podle Tomáše Akvinského stává kritériem rozumu pro jednání. Ctnost moudrosti či prozřetelnosti je tak základem všech ctností. Ona aplikuje rozumem poznaný cíl člověka, dobro, v konkrétní situaci. ${ }^{72}$ Těmito odkazy na Tomáše Akvinského papež František vyvrací kritiku, která byla vznesena na adresu jeho postojů formulovaných v Amoris laetitia a která je označuje za situační etiku. $\mathrm{S}$ odkazem na Josefa Piepera, který moudrostí nazývá situační svědomí, $\mathrm{k}$ tomu Walter Kasper dodává, že toto nemá nic společného se situační etikou, protože moudrost neodvozuje normu ze situace, nevytvář́ žádnou normu, naopak ji předpokládá a převádí ji na konkrétní situaci. ${ }^{73}$ Explicitně to vyjadřuje i Amoris laetitia, kde papež říká, že „,co je součástí praktického rozlišování $\mathrm{v}$ jednotlivé situaci, nemůže být povýšeno na úroveň normy. Vedlo by to nejen k neúnosné kazuistice, ale ohrozilo by to také hodnoty, které je třeba chránit se zvláštní pozorností. “74

\section{Závěr}

Apoštolská exhortace papeže Františka Amoris laetitia, která shrnuje a rozpracovává závěry dvou biskupských synod o rodině, nabízí řadu podnětů jak pro podobu církevní pastorační praxe, tak také pro oblast sociální práce, třebaže jsou mezi těmito dvěma oblastmi lidské praxe rozdíly. Pastorační práce, resp. role pastoračního pracovníka je určována specifickou kulturou života církve a jejího poslání, kterým je uvádění člověka do vztahu $\mathrm{k}$ Bohu. Pro pastoračního pracovníka to znamená napomáhat především formou doprovázení $\mathrm{k}$ uskutečňování osobního povolání člověka, které zahrnuje objevování, rozlišování a naplňování etických a spirituálních požadavků a potř̌eb, které mají vést dotyčného $\mathrm{k}$ plnohodnotnému a zdařilému životu; $\mathrm{v}$ manželství a rodině pak především $\mathrm{k}$ růstu kvality manželského vztahu a k rozpoznávání a naplňování manželské a rodinné odpovědnosti, resp. $\mathrm{k}$ začleňování do společenství církve, které se pro dotyčného (dotyčné) stává zázemím a zdrojem životní síly (milosti) a trvalé obnovy.

Role sociálního pracovníka je jiná, nejen $\mathrm{v}$ tom, jak bylo řečeno $\mathrm{v}$ úvodu tohoto pojednání, že sociální práce je cíleně zaměřena pouze na problémové jevy v životních oblastech manželství a rodiny, nýbrž také $\mathrm{v}$ tom, že se opírá o značně heterogenní sekulární kulturu. Jejím cílem není primárně snaha o ideové či hodnotové ukotvení klienta, resp. klientů, byt̉ otázku hodnot reflektuje, nýbrž umožnění jeho (jejich) sociálního fungování a naplňování s ním spojených požadavků a potřeb.

Na otázku z úvodu tohoto článku, zda a do jaké míry mohou být podněty obsažené ve výstupních dokumentech biskupských synod z podzimu 2014, resp. 2015 a v posynodální apoštolské exhortaci papeže Františka Amoris laetitia inspirativní i pro sociální práci, si můžeme odpovědět, že $\mathrm{v}$ rovině principiálních či metodických podnětů bezesporu ano.

Připomeňme zde především výše reflektované vyzdvižení osobní odpovědnosti pastoračních a sociálních pracovníků, která se nemůže skrýt za striktní aplikaci etické normy či zákona, za instituci církve ${ }^{75}$ nebo za nastavená kritéria či standardy pomáhající organizace v oblasti sociální práce. Dalším přínosným podnětem může být důraz na osobní angažovanou interakci mezi pastoračním pracovníkem, manžely a rodinou, resp. interakci mezi sociálním pracovníkem a klientem (klienty), která je určována logikou soucítění vůči těm, kdo jsou slabí, vyhýbá se jejich stí-

72 Srov. Summa theologiae I/II, q. 64, a. 1; De Virtutibus a. 13; Summa theologiea I/II, q. 57, a. 4; II/II, q. 47, a 2 s. c.; a. 6 . Srov. k tomu Walter KASPER, „Amoris laetitia“: Bruch oder Aufbruch?, s. 726.

73 Srov. tamtéž.

74 Amoris laetitia 304.

75 Srov. Amoris laetitia 305. 
hání nebo příliš tvrdým a unáhleným soudům a definitivnímu odsouzení, respektuje proces zrání člověka a je charakteristická časovou disponibilitou, vytrvalostí a trpělivostí. Rozdílnost „zázemí" pastoračního pracovníka a sociálního pracovníka přitom bude ve výsledku znamenat, že zatímco např. v Amoris laetitia kritizovaný nepřípadný postoj „soudce“ zastávaný pastoračním pracovníkem bude navozovat př́padnou otázku po důsledku dosud v církvi přetrvávajícího, z dnešního pohledu problematického, etického paradigmatu, tak v př́padě sociálního pracovníka bude zmiňovaný nepatřičný postoj vnímán především jako etické selhání profesionality, jako důsledek jeho osobní nezralosti či jako důsledek syndromu vyhoření či mesiášského komplexu.

\title{
Vybrané podněty biskupských synod o rodině $(2014,2015)$ a postsynodální apoštolské exhortace Amoris laetitia (2016) pro pomáhající profese
}

\begin{abstract}
Abstrakt
Článek reflektuje výpovědi posynodální apoštolské exhortace papeže Františka Amoris laetitia s cílem specifikovat její podněty pro pomáhající profese, církevní pastorační praxi a oblast sociální práce. Implicitně se zde řeší otázka, zda tyto podněty, které vychází z křestanského pohledu na svět a u zainteresovaných ho předpokládají, mají svoji relevanci pro sociální práci, u které tento pohled není podmínkou ani obecným standardem. Z tohoto důvodu článek nabízí rovněž stručný pohled na podobu a význam křest’anského etického paradigmatu v dějinách církve.
\end{abstract}

Klíčová slova: papež František, Amoris laetitia, manželství, rodina, pastorace, sociální práce, etika, doprovázení, rozlišování, integrace

\section{Kontakt na autora}

\section{doc. Jindřich Šrajer, Dr. theol.}

Jihočeská univerzita v Českých Budějovicích

Teologická fakulta, Katedra etiky, psychologie a charitativní práce

Kněžská 8, 37001 České Budějovice

srajer@tf.jcu.cz 